\title{
Illustration of the loss of haemodynamic coherence during atrial fibrillation using urethral photoplethysmography
}

\author{
Charles-Hervé Vacheron, Bernard Allaouchiche
}

Anesthésie Réanimation, Centre Hospitalier Lyon-Sud, PierreBénite, France

\section{Correspondence to}

Dr Charles-Hervé Vacheron, charles-herve.vacheron@chulyon.fr

Accepted 12 July 2019

\section{DESCRIPTION}

Figure 1 represents an episode of atrial fibrillation during 12 hours presented by one of our patient of 60 years admitted into intensive care unit during postoperative care of hyperthermic intraperitoneal chemotherapy procedure. Three parameters are represented: heart rate (green line) rising up at the start of the atrial fibrillation and returning to normal when the reduction occurs, mean arterial pressure (red line) dropping at the start while remaining stable during all the episodes including the reduction, and the Ikorus Perfusion Index (uPI, blue line), extracted from the photoplethysmographic signal of a specific urinary probe. The uPI is an index of tissue perfusion monitored continuously $^{1}$ : it drops drastically at the beginning of the arrhythmia, and returns to normal at the end of the episode, illustrating major tissue perfusion alteration, likely to induce tissue dysoxia. The uPI is calculated from a separation of the pulsatile signal and of the non-pulsatile signal, it is then defined as the integral of the absorbance of the pulsatile blood on a given time window. Due to the design of the probe, this quantity is proportional to the integral of the variation of total haemoglobin concentration weighted by the tissue oxygen saturation. This means that the variation of the uPI is akin to a variation of blow flow weighted by the (local) arteriolar blood saturation.

Atrial fibrillation is a common issue in anaesthesiology and intensive care unit. Current guidelines recommend acute restoration of a sinus rhythm in case of haemodynamic instability or severely depressed left ventricular ejection fraction. ${ }^{2}$ In our

imited 2019. No commercial re-use. See rights and permissions. Published by BMJ.

To cite: Vacheron $\mathrm{C}-\mathrm{H}$ Allaouchiche B. BMJ Case Rep 2019:12:e230757. doi:10.1136/bcr-2019230757

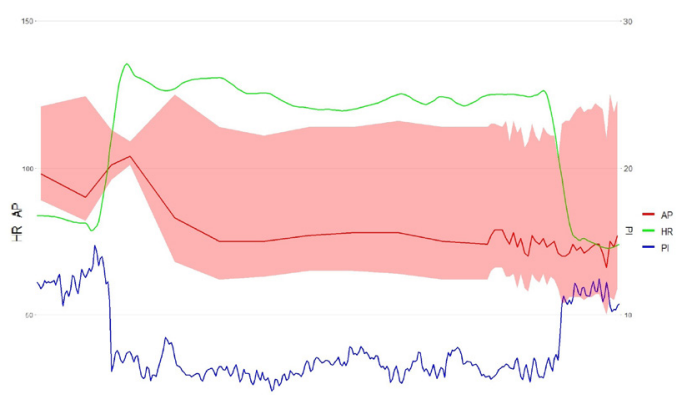

Figure 1 Evolution of $\mathrm{HR}, \mathrm{AP}$ and $\mathrm{PI}$ over time. $A P$, arterial blood pressure; $H R$, heart rate; $\mathrm{PI}$, Perfusion Index.

\section{Learning points}

Routine haemodynamic monitoring may mislead clinician in their appreciation of the tolerance of atrial fibrillation.

- Continuous monitoring of the microcirculation is a key parameter to correctly assessed our patient into anaesthesia or intensive care.

patient, there were no conventional criteria of poor tolerance of atrial fibrillation, despite the alteration of the tissue perfusion.

This dissociation between macrocirculation and microcirculation during atrial fibrillation has already been documented. Fornier et al reported in 25 postoperative patients that severe defect of microcirculation during atrial fibrillation monitored with near-infrared spectroscopy (NIRS) probe on the forearm without haemodynamic instability which significantly improved following return to sinus rhythm.

The uPI used in this study is extracted from an innovative device consisting of an urinary catheter equipped with a photoplethysmography sensor in contact with the urethral mucosa, and allows without any additional equipment of the patient, the continuous monitoring of the tissue perfusion.

This image highlights the discrepancy between comforting systemic haemodynamic values monitored, and the concurrent severe alteration of tissue perfusion. They illustrate the importance for new progress into the routinely available monitoring of tissue perfusion.

Contributors $\mathrm{CHV}$ and BA wrote the case and worked on the image.

Funding The authors have not declared a specific grant for this research from any funding agency in the public, commercial or not-for-profit sectors.

Competing interests BA is a consultant for APD.

Patient consent for publication Obtained.

Provenance and peer review Not commissioned; externally peer reviewed.

\section{REFERENCES}

1 Jacquet-Lagrèze M, Bonnet-Garin JM, Allaouchiche B, et al. A new device for continuous assessment of gut perfusion: proof of concept on a porcine model of septic shock. Crit Care 2014;18:R153.

2 Kirchhof P, Benussi S, Kotecha D, et al. ESC Guidelines for the management of atrial fibrillation developed in collaboration with EACTS. Eur Heart J 2016;2016:2893-962. 
Images in...

3 Fornier W, Jacquet-Lagrèze $\mathrm{M}$, Collenot T, et al. Microvascular effects of intravenous esmolol in patients with normal cardiac function undergoing postoperative atrial

Copyright 2019 BMJ Publishing Group. All rights reserved. For permission to reuse any of this content visit

https://www.bmj.com/company/products-services/rights-and-licensing/permissions/

BMJ Case Report Fellows may re-use this article for personal use and teaching without any further permission.

Become a Fellow of BMJ Case Reports today and you can:

- Submit as many cases as you like

- Enjoy fast sympathetic peer review and rapid publication of accepted articles

- Access all the published articles

Re-use any of the published material for personal use and teaching without further permission

Customer Service

If you have any further queries about your subscription, please contact our customer services team on +44 (0) 2071111105 or via email at support@bmj.com.

Visit casereports.bmj.com for more articles like this and to become a Fellow 